\title{
ОСОБЛИВОСТІ РЕІНТЕГРАЦІЇ ОСІБ, ЗВІЛЬНЕНИХ 3 МІСЦЬ ПОЗБАВЛЕННЯ ВОЛІ, У ХРИСТИЯНСЬКИХ РЕАБІЛІТАЦІЙНИХ ЦЕНТРАХ
}

3'ясовано особливості реінтеграції осіб, звільнених з місць позбавлення волі, у християнських реабілітаційних центрах. На відміну від алко- і наркозалежних осіб, у яких сенсом реінтеграції $€$ позбавлення залежностей, у зазначеної категорії таким сенсом $€$ : зміна асоціальної моделі поведінки на просоціальну; засвоєння просоціальних практик вирішення життєвих завдань; забезпечення сталого зв'язку з релігійною громадою, а через неї - із соціальним оточенням. Показано, що запорукою успішності процесу реінтеграції цих особистостей $\epsilon$ контекст духовної родини релігійної громади, соціальна підтримка та соціальнопсихологічний супровід осіб, звільнених з місць позбавлення волі, громадськими релігійними організаціями. На основі емпіричного дослідження життєвих історій 30 успішних осіб, звільнених 3 місць позбавлення волі, які не мали рецидивів асоціальної поведінки впродовж п'яти років після закінчення курсу реабілітації, визначено значущі чинники ефективності їхньої реінтеграції. До основних таких чинників віднесено успішне вирішення найважливіших життєвих завдань: отримання робочого місця, створення або возз'єднання сім'ї та активна участь у громадському житті, які взаємно стимулюють і підсилюють одне одного (про це свідчать тісні кореляційні зв'язки, які простежуються між перемінними "Оволодіння новою професією” і “Створення або оновлення сім'ї”, між перемінними “Оволодіння новою професією” і “Активна участь у громадському житті”). Як основні критерії успішності реінтеграції розглянуто засвоєння просоціальних практик у вирішенні особистістю своїх життєвих завдань та відсутність рецидивів порушень правових норм і законів суспільного життя.

Ключові слова: чинники реінтеграції, звільнені з місць позбавлення волі, соціальна модель поведінки, життєві завдання, просоціальні практики, християнські центри, релігійна громада.

H. I. Hladii

\section{REINTEGRATION FEATURES OF PERSONS RELEASED FROM PRISONS, IN CHRISTIAN REHABILITATION CENTERS}

There are revealed the reintegration peculiarities of persons released from places of imprisonment, in Christian rehabilitation centers. Unlike alcohol and drug addicts, in which reintegration means deprivation from dependencies, the mentioned category has such a sense: the shift from an asocial behavior model to a social one; the assimilation of prosocial practices in life problems solving; the provision of a stable relationship with a religious community and through it - with a social environment. It is shown that the condition for success of reintegration process of these individuals is the context of spiritual family in a religious community, the social support and socio-psychological assistance of persons released from prisons by public religious organizations. Based on the empirical study of life stories of 30 successful people released from prisons who didn't show the recurrence of antisocial 
behavior within five years after the rehab course completion, it is found the significant factors for the effectiveness of their reintegration. The basic ones among them are the successful solution of main life tasks: obtaining a place of work, the creation or renewal of a family and active participation in community life. These factors mutually stimulate and reinforce each other. This is evidenced by strong correlation between the variables "Acquiring a new profession" and "Creating or renewal of a family", between the variables "Acquiring a new profession" and "Active participation in public life". As the main criteria for reintegration success there are indicated the assimilation of prosocial practices in personal life tasks solving and the recurrence absence in violations of legal norms and laws of social life.

Key words: factors of reintegration, persons released from prisons, social model of behavior, life tasks, prosocial practices, Christian centers, religious community.

Постановка проблеми. Актуальною для українського суспільства залишається наразі проблема забезпечення належної реінтеграції осіб, звільнених $з$ місць позбавлення волі (далі - ОЗМПВ). Згідно 3 інформацією, наданою “Донецькому Меморіалу” Державною пенітенціарною службою України, у місцях позбавлення волі кримінальновиконавчої системи України, які контролюються українською владою, тобто без установ Криму та окупованої частини Донецької та Луганської областей, протягом 2017 року з установ виконання покарань звільнилося 11367 осіб (15841 особа за 2016 р.), а потрапило в ці установи знову засуджених осіб 8083 (21651 особа за 2016 р.). Як свідчать оприлюднені дані, станом на 1 січня 2016 року у 32 установах середнього рівня безпеки для неодноразово засуджених утримувалося 18168 осіб (22 780 осіб) [1]. Тобто число людей, які повторно скоюють злочини після відбування покарання, становить значну частку щодо всіх засуджених осіб (понад 30\% від загальної чисельності засуджених). Забезпечити ефективність процесу реінтеграції ОЗМПВ мають заходи, передбачені міжнародними і державними нормативними документи та програмами.

Важливу роль у процесі реінтеграції ОЗМПВ відіграють різноманітні соціальні інститути. Згідно з інформацією, наданою Міністерством соціальної політики України, станом на 1 січня 2017 року послуги 3 реабілітації, ресоціалізації та реінтеграції ОЗМПВ надаються державними і недержавними організаціями. Загалом соціальний супровід i соціальний патронаж таких осіб здійснюють 217 суб’єктів, серед яких 119 є недержавними організаціями [2]. Переважна білышість недержавних організацій - це християнські релігійні організації, які є засновниками відповідних центрів реабілітації (далі - ХРЦ, або Центр). Як повідомляє Асоціація ХРЦ, в Україні налічується на цей час близько 120 реаблітаційних центрів різноманітних деномінацій. Протягом року понад 5000 осіб у цих центрах проходять курс реабілітації [3]. 3 нашого досвіду, близько третини цих людей - це особи, які звільнилися 3 місць позбавлення волі. У цілому ХРЦ мають на меті допомогти учасникам позбавитися різного роду залежностей на основі засвоєння християнського 
світогляду і способу життя. Зазначимо, що певна частина ОЗМПВ має повторні судимості за порушення законодавства, пов'язані з незаконним виробництвом, виготовленням, придбанням, зберіганням, перевезенням, пересиланням чи збутом наркотичних засобів, психотропних речовин або їх аналогів. Однак значна частина ОЗМПВ має судимості за інші порушення законодавства (шахрайство, вимагання, крадіжки, вбивства тощо). Тому у фокусі нашої уваги - визначення особливостей реінтеграції ОЗМПВ, які перш за все мають потребу в засвоєнні просоціального способу життя, а не лише у звільненні від залежностей.

Аналіз останніх досліджень і публікацій. Як правило, у відомих нам роботах реабілітація ОЗМПВ у ХРЦ не виділяється в окреме завдання, однак наразі є численні дослідження реабілітаційного процесу, проведені зарубіжними і вітчизняними авторами. Так, Ch. R. Allen, I. H. Almarooqi, S. M. Alniyadi, T. Atabay, K. Bruckmller, E. Carranza визначили особистісні моделі реінтеграції різних груп ОЗМПВ; N. Hudiak, Ю. Лазарева з'ясували етапи та організаційні форми, методики і програми реінтеграції, Ю. Валентик, М. Kotański обгрунтували необхідність створення для учасників реабілітаційних програм окремих терапевтичних груп [4-7].

У колективному дослідженні вітчизняних учених В. Жуковського, О. Климишин, Т. Лозинської обгрунтовано модель, етапи, форми реабілітаційного процесу на основі християнської психології [8, с. 236-280]. У роботах О. Карамана, В. Бадира, В. Проскури визначено основні характеристики процесу реінтеграції ОЗМПВ [9, с. 17-22]. Н. Грачук, Л. Шевченко дослідили гендерні відмінності засуджених жінок та чоловіків $[10 ; 11]$. Б. Лазоренко аналізує труднощі, 3 якими їм доводиться стикатися, щоб подолати страх перед суспільством, вплив духовного, фізичного і психічного здоров'я на процес реінтеграції [12, c. 83-88]. Напрацювання цих авторів ми врахували у своєму дослідженні.

Не вирішені раніше частини загальної проблеми. У ході аналізу згаданого вище наукового доробку було виявлено, що наразі бракує емпіричних досліджень особливостей, чинників і критеріїв реінтеграції ОЗМПВ у християнських реабілітаційних центрах та громадах, що, безперечно, важливо з погляду підвищення ефективності реабілітації та реінтеграції цих осіб у сучасне українське суспільство.

Метою статті $\epsilon$ визначення особливостей успішної реінтеграції в сучасне українське суспільство ОЗМПВ, які пройшли курс реабілітації в ХРЦ. Завдання дослідження - визначити умови і соціально-психологічні чинники, які забезпечують успішність реінтеграції ОЗМПВ, критерії ефективності цього процесу.

Виклад основного матеріалу дослідження. Коли йдеться про ОЗМПВ, то слід мати на увазі, що більшість із них ще з підліткового віку була соціалізована в кримінальну субкультуру і набула сталих кримінальних практик. Тому особи, які вирішили опанувати новий, 
законослухняний, спосіб життя мають радикально трансформувати власну особистість, набути нового світогляду, замінити кримінальні практики на просоціальні, навчитися вирішувати життєві завдання відповідно до моральних норм і правових законів сучасного українського суспільства. 3 огляду на це процес реінтеграції ОЗМПВ має два основні етапи. Перший, який назагал відбувається в ХРЦ, ставить за мету звільнення від асоціальної моделі поведінки і набуття просоціальної їі моделі, визначення основних життєвих завдань, які ОЗМПВ мають вирішити по закінченні курсу реабілітації в ХРЦ, щоб забезпечити новий, правослухняний, спосіб життя. Другий етап - це набуття та закріплення нових, просоціальних, практик вирішення основних життєвих завдань. Такими практиками є: здобуття професійної освіти; робота за професією; вирішення проблеми власного житла (якщо його немає); відновлення або створення сім’ї саме в контексті правослухняного співжиття громадян сучасного українського суспільства.

Розгляньмо більш конкретно ці два етапи. Перебування в ХРЦ починається із прийняття його норм і правил, що забезпечують інгібіцію асоціальної моделі поведінки і набуття просоціальних знань, настановлень, умінь і навичок нової, просоціальної, моделі поведінки, яка формуються завдяки простим навичкам побуту i спілкування, забезпечення своїх безпосередніх життєвих потреб [12, с. 70-76; 13, с. 90-113; 14, с. 126]. Слід зазначити, що суттєвою особливістю процесів реабілітації в ХРЦ є побудова їхньої життєдіяльності на сімейно-родинних засадах. Проте, на відміну від звичайних сімей і родин, які будуються на кровній спорідненості і взаємній відповідальності за родичів, ХРЦ будується на духовній єдності життєвих цінностей, спілкуванні, взаємодопомозі і взаємній підтримці. Перебуваючи в центрі, ОЗМПВ зосереджують свою увагу на освіті і самоосвіті, працюють над собою, своїми навичками, характером, вчаться по-новому мислити і спілкуватись, планувати свій час і керувати поведінкою. Вони також вчаться аналізувати свої помилки i виносити вважливі життєві уроки, а головне - визначають найважливіші життєві завдання, які мають вирішити після виходу із ХРЦ у самостійне життя.

Практика реабілітаційної роботи з ОЗМПВ свідчить про те, що, поки вони перебувають у ХРЦ, у них не виникає проблем із законом, оскільки їхні основні життєві потреби задовольняються самою організацією життя в центрі. Проте по завершенні періоду перебування в ХРЦ у разі зіткнення сам-на-сам із соціальною реальністю ОЗМПВ можуть повернутися до попередньої асоціальної моделі поведінки та кримінальних практик. Успішність процесу реінтеграції ОЗМПВ у соціум залежить від ефективності соціальної підтримки і соціально-психологічного супроводу в постреабілітаційний період, їх адекватного включення у звичайне соціальне життя, Таку підтримку і супровід надає релігійна 
громада, яка зберігає і далі забезпечує для ОЗМПВ духовний сімейнородинний контекст, започаткований у ХРЦ.

Соціально-психологічним змістом другого етапу реінтеграції ОЗМПВ $є$ вирішення ними важливих життєвих завдань на основі нових, духовних, цінностей, життєвих компетенцій, соціальних та моральних норм суспільства. Головним результатом цього етапу $\epsilon$ набуття і закріплення просоціальних практик як головних засобів вирішення цих завдань. При цьому ОЗМПВ розширюють і вдосконалюють спілкування в контексті духовної родини. Релігійна громада та ії члени разом із працівниками центрів забезпечують соціальний простір, зворотний зв'язок, соціально-психологічний супровід і підтримку процесу реінтеграції випускників реабілітаційних центрів у свою спільноту. Також релігійна громада опосередковує взаємодію та інтеграцію випускників ХРЦ із зовнішнім соціальним середовищем, своєрідно регулює, відповідно до власної субкультури, їхні стосунки і поведінку в цьому середовищі.

Щоб емпіричним шляхом визначити особливості та результати реінтеграції випускників християнських центрів в український соціум, ми залучили до дослідження 30 осіб (22 чоловіки віком від 28 до 50 років і 8 жінок віком від 27 до 52 років), які проходили реабілітацію протягом п'яти років поспіль, а потім успішно інтегрувались у суспільство і за цей період дотепер не мають проблем із законом. Основні методи дослідження - відеоінтерв'ювання цих осіб, аналіз їхніх життєвих історій методом Ф. Щюца, а також статистичне опрацювання отриманих даних за допомогою програми SPSS 20,0.

У ході дослідження респонденти розділилися на дві групи: перша це ті ОЗМПВ, які проходили реабілітацію у форматі амбулаторного денного центру перебування при релігійній громаді і брали участь у реабілітаційних сесіях 2-3 рази на тиждень. Таких у вибірці виявилося 5 осіб (10\% від загальної кількості). Другу групу склали особи, які пройшли курс реабілітації в стаціонарному форматі; вони становили більшість досліджуваних - 22 особи (90\%).

Як показало опитування респондентів, найважливішими для випускників ХРЦ життєвими завданнями по забезпеченню власних життєвих потреб після проходження курсу ресоціалізації на другому етапі реінтеграції були такі:

- пошук роботи або вибір навчального закладу, курсів;

- оволодіння новою професією або підвищення своєї кваліфікації;

- створення нової сім'ї або оновлення зв'язків із сім'єю, яка вже існує;

- відновлення та підтримка здоров'я.

Також важливими щодо забезпечення ефективності процесу реінтеграції виявилися зовнішні та внутрішні ії чинники. Найчастіше серед зовнішніх чинників реінтегращії респонденти згадували: соціальний 
тиск органів правопорядку, колишньої сім’ї, колишніх співучасників по кримінальних справах; труднощі забезпечення свого життя за допомогою кримінальних практик; вплив позитивних прикладів товаришів, які стали на просоціальний шлях, наставників центру, лідерів громади. Як важливі внутрішні чинники учасники дослідження зазвичай називали: потяг до нового, щасливого життя; прагнення довести собі та близькому оточенню свою спроможність жити по-новому; бажання виправдати надії і довіру близьких та наставників, лідерів громади; успіхи в набутті нових знань, умінь і навичок у побуті, спілкуванні, навчанні; позитивні результати нових практик спілкування і задоволення своїх потреб та інтересів.

На основі аналізу життєвих історій успішних ОЗМПВ встановлено, що одним із важливих чинників ефективності реінтеграції $є$ активна участь у громадському житті. Так, 28 респондентів із 30 є лідерами громадського життя, 20 осіб (67\%) стали керівниками громадських організацій (безкоштовно), ще 8 (27\%) - керівниками громадських рад (безкоштовно).

Про досягнуті результати та успіхи реінтеграції свідчать життєві історії респондентів (табл.).

Таблиця

Життсві історії випускників реабілітаційних центрів

\begin{tabular}{|c|c|c|}
\hline Ім'я, вік & Кримінальне минуле & Результати реінтеграції \\
\hline $\begin{array}{l}\text { Сергій, } \\
36 \text { років }\end{array}$ & $\begin{array}{l}\text { У } 16 \text { років полишив спорт, } \\
\text { прилучився до бандитизму, } \\
\text { рекету. Вживання героїну. } \\
\text { Засудження, відбування } \\
\text { покарання }\end{array}$ & $\begin{array}{l}\text { Закінчив курс реабілітації “Морська піхота”, } \\
\text { духовну академію “Ісус Навин”. Соціальний } \\
\text { пастор, бізнесмен. Служіння залежним і } \\
\text { проблемним людям. Одружений, } 2 \text { дітей }\end{array}$ \\
\hline $\begin{array}{l}\text { Роман, } \\
38 \text { років }\end{array}$ & $\begin{array}{l}316 \text { років член злочинного } \\
\text { угруповання. Незаконне } \\
\text { збагачення, вживання } \\
\text { наркотиків. Засудження, } \\
\text { відбування покарання }\end{array}$ & $\begin{array}{l}\text { Закінчив курс реабілітації в центрі, ННПУ } \\
\text { ім. М. П. Драгоманова. Психолог, заступник } \\
\text { керівника громадської ради при Міністерстві } \\
\text { соціальної політики. Консультування } \\
\text { проблемних людей. Одружений, } 1 \text { дитина }\end{array}$ \\
\hline $\begin{array}{l}\text { Андрій, } \\
38 \text { років }\end{array}$ & $\begin{array}{l}313 \text { років вживання та збут } \\
\text { наркотиків. Засудження, } \\
\text { відбування покарання }\end{array}$ & $\begin{array}{l}\text { Закінчив курс реабілітації в центрі. Лідер } \\
\text { громади, бізнесмен, пастор церкви. Служіння } \\
\text { сімейним парам, дошлюбне служіння. Одру- } \\
\text { жений, } 2 \text { дітей }\end{array}$ \\
\hline $\begin{array}{l}\text { Олена, } \\
40 \text { років }\end{array}$ & $\begin{array}{l}319 \text { років незаконне } \\
\text { збагачення, наркотики. } \\
\text { Засудження, відбування } \\
\text { покарання }\end{array}$ & $\begin{array}{l}\text { Пройшла курс реабілітації в центрі. Здобула } \\
\text { вищу освіту за спеціальністю “соціальна пси- } \\
\text { хологія”, соціальний пастор, капелан (робота із } \\
\text { засудженими жінками). Одружена, } 3 \text { дітей }\end{array}$ \\
\hline $\begin{array}{l}\text { Світлана, } \\
45 \text { років }\end{array}$ & $\begin{array}{l}313 \text { років вживання мари- } \\
\text { хуани, } 315 \text { років - ефедри- } \\
\text { ну, у } 16 \text { років - вагітність, у } \\
18 \text { років - перше засуджен- } \\
\text { ня (загалом їх п'ять) }\end{array}$ & $\begin{array}{l}\text { Закінчила курс реабілітації. Лідер громади, } \\
\text { бізнесмен, пастор церкви. Президент громадсь- } \\
\text { кої організації. Веде жіноче служіння допомо- } \\
\text { ги важковиховуваним підліткам. Одружена, } \\
2 \text { дітей }\end{array}$ \\
\hline
\end{tabular}

Результати дослідження показали, що значущою умовою, яка забезпечує ефективність реінтеграції ОЗМПВ, є соціальна допомога 
релігійної громади, яка опікується ними, і надаваний нею соціальнопсихологічний супровід. Визначено, що підтримка просоціального способу життя ОЗМПВ по завершенні ними курсу реабілітації в Центрі надається в різних формах. Це участь у школах духовного зростання, групах взаємодопомоги, тренінгах, майстер-класах; участь у різноманітних громадських служіннях (сімейному, дитячому, дошлюбних стосунків); волонтерська допомога учасникам ХРЦ; участь у групах спілкування і взаємної підтримки в соціальних мережах. Завдяки різноманітності форм підтримки кожен учасник реабілітаційного центру може обрати для себе ті з них, які найбільшою мірою відповідають його особистості.

Також з'ясовано, що успішні ОЗМПВ зазвичай поєднують працю, аби матеріально забезпечувати себе і свою сім'ю, з активною участю у громадському житті. Допомагаючи іншим, вони посилюють свою відповідальність за них і за свій спосіб життя, підвищують власну самооцінку, впевненість у правильності своїх дій і тим самим закріплюють просоціальні практики та спосіб життя. У цілому таке поєднання сприяє зміцненню мотивації колишніх ОЗМПВ до активного позитивного життя, укоріненню на основі духовних цінностей їхніх просоціальних практик. Завдяки участі в різноманітних формах зазначених вище активностей, продуктивному обміну досвідом відбувається поглиблення впевненості в собі, що посилює віру в себе і свої можливості, рішучість у досягненні поставлених життєвих цілей. Активна участь ОЗМПВ у різних заходах громадського життя громади розвиває їхні комунікативні здібності, дисциплінованість, відповідальність за себе та інших учасників, уміння вибудовувати гармонійні міжособові стосунки, більш ефективно вирішувати свої життєві завдання.

Результати емпіричного дослідження підтверджують ці висновки. Скориставшись програмою SPSS 20,0 і методом Краскала - Уолліса, ми проаналізували зв'язок між перемінними, що позначають реалізацію найсуттєвіших життєвих завдань. 3'ясувалося, що тісні кореляційні зв'язки пов'язують змінні “Оволодіння новою професією” і “Створення або відновлення сім' '̈’” $(\mathrm{R}=0,562)$, а також змінні “Оволодіння новою професією” і “Активна участь у громадському житті” ( $\mathrm{R}=0,613)$. Отже, завдяки взаємодії і взаємній стимуляції практик реалізації зазначених життєвих завдань посилюється загальна ефективність реінтеграції ОЗМПВ у сучасне українське суспільство.

3 огляду на результати нашого дослідження можемо відтак визначити два основні критерії успішності реінтеграції ОЗМПВ - випускників ХРЦ. Перший - це засвоєння ними нових, просоціальних, практик у вирішенні основних життєвих завдань; застосування цих практик зумовлює самодостатність і спроможність випускників успішно долати власні життєві проблеми згідно із законами, правилами і нормами су- 
спільства. Другий - це те, що серед випускників центрів немає рецидивів порушень правових норм і законів суспільного життя.

Висновки. Порівнявши мотивацію учасників реабілітаційного курсу при ХРЦ ми з'ясували, що, на відміну від алко- та наркозалежних ОЗВМП, основним мотивом яких $є$ звільнення від цих залежностей, визначальним мотивом інших ОЗВМП є зміна асоціальної моделі поведінки на просоціальну та набуття просоціальних практик вирішення своїх життєвих завдань. Така мотивація зумовлює спрямованість їхньої реабілітації та забезпечує успішність реінтеграції в суспільне життя.

Визначено два основних етапи реінтеграції ОЗМПВ: перший реабілітація в ХРЦ, що передбачає опанування просоціальної моделі поведінки та визначення основних життєвих завдань, які потребують вирішення після завершення реабілітації; другий - засвоєння просоціальних практик реалізації життєвих завдань на основі просоціальної моделі поведінки.

Аналіз життєвих історій 30 успішних ОЗМПВ, які не мали рецидивів асоціальної поведінки впродовж п'яти років після закінчення курсу реабілітації, дав змогу виокремити значущі чинники ефективності їхньої реінтеграції. До провідних внутрішніх чинників віднесено потяг до нового, щасливого життя та бажання виправдати надії і довіру близьких та наставників, лідерів громади, до зовнішніх - труднощі в забезпеченні свого життя за допомогою кримінальних практик і вплив позитивних прикладів товаришів, які обрали просоціальний спосіб життя. Основними чинниками слід вважати ті, які сприяли успішному вирішенню життєвих завдань: отримання робочого місця; створення сім’і та активну участь у громадському житті спільноти, які взаємно стимулюють і підсилюють одне одного. Це підтверджується наявністю тісних кореляційних зв'язків, які пов'язують між собою змінні “Оволодіння новою професією” i “Створення або відновлення сім' $\mathrm{i}$ ” $(\mathrm{R}=0,562)$, між перемінними “Оволодіння новою професією” і “Активна участь у громадському житті” $(\mathrm{R}=0,613)$.

Показано, що суттєвою умовою успішності реінтеграції ОЗМПВ у сучасне українське суспільство $€$ контекст духовної родини, який забезпечує релігійна громада, її соціальна підтримка та соціально-психологічний супровід.

Як основні критерії успішності реінтеграції визначено засвоєння особами, звільненими з місць позбавлення волі, просоціальних практик для вирішення своїх життєвих завдань, що дає змогу уникати рецидивів порушень правових норм і законів суспільного життя.

Подальші дослідження процесу реінтеграції випускників реабілітаційних центрів будуть спрямовані на розкриття взаємозв'язку соціально-психологічних практик і моделей поведінки. 


\section{Список використаних джерел}

1. “Донецький Меморіал”. Діяльність кримінально-виконавчої системи України у 2015, 2016, 2017 роках. Статистичний огляд. Взято 3 http://ukrprison. org.ua/articles/1453132032.

2. Інформація про виконання Плану заходів з реалізації Концепції соціальної адаптації осіб, які відбували покарання у вигляді позбавлення волі на певний строк, до 2015 року, затвердженого розпорядженням Кабінету Міністрів України від 01.07.2009 №740-p. Взято 3 https://goo.gl/E9p6rZ.

3. Ассоциация христианских центров реабилитации. (2011). Взято 3 http://ahcr.com.ua/2011-12-12-15-07-53.html.

4. Manuel d'introduction pour la Prévention de la Récidive et la Réinsertion Sociale des Délinquants. (2013). Retrieved from https://www.unodc.org/ documents/justice-and-prison-reform/UNODC_SocialReintegration_FRE_ 180313.pdf.

5. Гудяк, Н. (2014). Організація соціальної роботи в Швеції. Social Work and Education, (1), 20-29. Взято з http://journals.uran.ua/swe/article/view/67767/ 63038.

6. Валентик, Ю. В. (2001). Реабилитационные иеетры “Casa Famiglia Rosetta”. 20-летний опыт работы (с. 1-120). Москва.

7. Лазарева, Ю. В. (2010). Современные проблемы социальной реабилитации лиц, освободившихся из мест лишения свободы. Всероссийский криминологический журнал, (1), 50-53. Взято из https://cyberleninka.ru/article/n/ sovremennye-problemy-sotsialnoy-reabilitatsii-lits-osvobodivshihsya-iz-mestlisheniya-svobody.

8. Жуковський, В. М. (Ред.). (2014). Побудова системи реабілітаџії адитивних осіб на основі християнської психологіï. Острог: Видавництво Національного університету “Острозька академія".

9. Проскура, В. В. (2015). Роль церкви у ресоціалізації засуджених до позбавлення волі. Соціальна політика і соціологія, 2(53), 17-22.

10. Грачук, Н. В. (2010). Гендерний підхід у ресоціалізації неповнолітніх осіб жіночої статі в умовах виховної колонії. Науковий вісник Волинського національного університету ім. Лесі Украӥнки. Юридичні науки, (24), 18-22.

11. Шевченко, Л. О. (2012). Гендерні моделі поведінки злочинців. Право $i$ Безпека, 4, 352-355. Взято з http://nbuv.gov.ua/UJRN/Pib_2012_4_78.

12. Лазоренко, Б. П. (Ред.). (2007). Проблемна молодь: иляхи сайоздійснення. Київ: Педагогічна думка.

13. Титаренко, Т. М. (Ред.). (2016). Психологія життєтворення особистості у сучасному світі. Київ: Міленіум.

14. Гладій, Г. І. (2013). Особливості ресочіалізації проблемної молоді в сучасних умовах Украӥни. Взято з http://oldconf.neasmo.org.ua/node/2943.

\section{References}

1. "Donetskyi Memorial". Diialnist kryminalno-vykonavchoi systemy Ukrainy u 2015, 2016, 2017 rokakh. Statystychnyi ohliad. [Donetsk Memorial. Activities of the Ukrainian Criminal Execution System in 2015, 2016, 2017. Statistical review]. Retrieved from http://ukrprison.org.ua/articles/1453132032 (ukr).

2. Informatsiia pro vykonannia Planu zakhodiv $\mathrm{z}$ realizatsii Kontseptsii sotsialnoi adaptatsii osib, yaki vidbuvaly pokarannia u vykhladi pozbavlennia voli na pevnyi strok, do 2015 roku, zatverdzhenoho rozporiadzhenniam Kabinetu 
Ministriv Ukrainy vid 01.07.2009 №740-r. [Information on the implementation of the Action Plan for the implementation of the Concept of Social Adaptation of Persons Serving Penitentiary in the Form of Detention for a Specified Period by 2015, approved by the Cabinet of Ministers of Ukraine order from 07.07.2009 No. 740-r.] Retrieved from https://goo.gl/E9p6rZ (ukr).

3. Assotsiatsiya khristianskikh tsentrov reabilitatsii [Association of Christian Centers]. Retrieved from http://ahcr.com.ua/2011-12-12-15-07-53.html (rus).

4. Manuel d'introduction pour la Prévention de la Récidive et la Réinsertion Sociale des Délinquants [Introductory Manual for the Prevention of Repetition and Social Reintegration of Offenders]. Retrieved from https://www.unodc.org/ documents/justice-and-prison-reform/UNODC_SocialReintegration_FRE_ 180313.pdf (french).

5. Hudiak, N. (2014). Orhanizatsiia sotsialnoi roboty v Shvetsii [Organization of social work in Sweden]. Social Work and Education, (1), 20-29. Retrieved from http://journals.uran.ua/swe/article/view/67767/63038 (ukr).

6. Valentyk, Yu. V. (2001). Reabilitatsionnyye tsentry "Casa Famiglia Rosetta": 20-letniy opyt raboty [Casa Famiglia Rosetta Rehabilitation Centers: 20 years of experience]. Moscow, pp. 1-120 (rus).

7. Lazareva, Yu. V. (2010). Sovremennyye problemy sotsialnoy reabilitatsii lits, osvobodivshikhsya iz mest lisheniya svobody [Contemporary issues of social rehabilitation of persons released from prison]. Vserossiyskiy kriminologicheskiy zhurnal, (1), 50-53. Retrieved from https://cyberleninka.ru/article/n/ sovremennye-problemy-sotsialnoy-reabilitatsii-lits osvobodivshihsya-iz-mestlisheniya-svobody (rus).

8. Zhukovskyi, V. M. (Ed.). (2014). Pobudova systemy reabilitatsii adytyvnykh osib na osnovi khrystyianskoi psykholohii [Construction of rehabilitation system for addicts on the basis of Christian psychology]. Ostroh: Vydavnytstvo Natsionalnoho universytetu "Ostrozka akademiia" (ukr).

9. Proskura, V. V. (2015). Rol tserkvy u resotsializatsii zasudzhenykh do pozbavlennia voli [The role of church in the resocialization of the convicted persons]. Sotsialna polityka i sotsiolohiia, 2(53), 17-22 (ukr).

10. Hrachuk, N. V. (2010). Hendernyi pidkhid u resotsializatsii nepovnolitnikh osib zhinochoi stati $\mathrm{v}$ umovakh vykhovnoi kolonii. [Gender approach in the resocialization of juvenile women in the educational colony]. Naukovyi visnyk Volynskoho natsionalnoho universytetu im. Lesi Ukrainky. Yurydychni nauky, (24), 18-22 (ukr).

11. Shevchenko, L. O. (2012). Henderni modeli povedinky zlochyntsiv [Gender behavior patterns of criminals]. Pravo i Bezpeka, (4), 352-355. Retrieved from http://nbuv.gov.ua/UJRN/Pib_2012_4_78_(ukr).

12. Lazorenko, B. P. (Ed.). (2007). Problemna molod: shliakhy samozdiisnennia [Problem youth: ways of self-realization]. Kyiv: Pedahohichna dumka (ukr).

13. Tytarenko, T. M. (Ed.). (2016). Psykholohiia zhyttietvorennia osobystosti $u$ suchasnomu sviti [Psychology of the person's life-formation in the modern world]. Kyiv: Milenium (ukr).

14. Hladii, H. I. (2013). Osoblyvosti resotsializatsii problemnoi molodi v suchasnykh umovakh Ukrainy [The features of resocialization of problem youth in the modem conditions of Ukraine]. Retrieved from http://oldconf. neasmo.org.ua/node/2943 (ukr). 